\title{
Can wetland plant functional groups be spectrally discriminated?
}

\author{
Alanna J. Rebelo ${ }^{\mathrm{a}, \mathrm{b}, *, 1}$, Ben Somers ${ }^{\mathrm{c}, 1}$, Karen J. Esler ${ }^{\mathrm{b}, \mathrm{d}, 1}$, Patrick Meire ${ }^{\mathrm{a}, 1}$

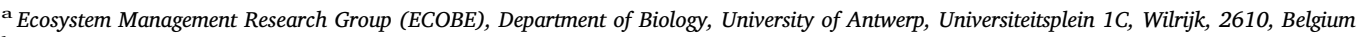 \\ ${ }^{\mathbf{b}}$ Department of Conservation Ecology and Entomology, Stellenbosch University, JS Marais Building, Victoria Street, Private Bag X01, Matieland, 7602 Stellenbosch, South \\ Africa \\ ${ }^{c}$ Division Forest, Nature \& Landscape, KU Leuven, Celestijnenlaan 200E, 3001 Leuven, Belgium \\ ${ }^{\mathrm{d}}$ Centre for Invasion Biology (C.I.B), Stellenbosch, South Africa
}

\section{A R T I C L E I N F O}

\section{Keywords:}

Ecosystem service mapping

South African palmiet wetlands

Hyperspectral

Spectroscopy

Biochemical plant traits

Spectral separability

Partial least squares regression (PLSR)

Redundancy analysis (RDA)

\begin{abstract}
A B S T R A C T
Plant functional traits (PFTs) underpin ecosystem processes and therefore ecosystem service provision. If PFTs are possible to detect and discriminate spectrally, then it may be possible to use remote sensing applications to map ecosystem processes or services within and across landscapes. As a first step towards this application, we explored whether functional groups of 22 dominant South African wetland species were spectrally separable based on their PFTs. We measured 23 biochemical and morphological PFTs in combination with spectra from 350 to $2349 \mathrm{~nm}$ using a handheld radiometer. First, we evaluated the possibility of accurately predicting morphological and biochemical PFTs from reflectance spectra using three approaches: spectrum averaging, redundancy analysis (RDA), and partial least squares regression (PLSR). Second, we established whether functional groups and species were spectrally distinguishable. We found seven PFTs to be important in at least two of the three approaches: four morphological and three biochemicals. Morphological traits that were important were leaf area (PLSR: $r^{2}=0.40$, regression: $\left.r^{2}=0.41\right)$, specific leaf area $\left(r^{2}=0.67\right)$, leaf mass $\left(r^{2}=0.43, r^{2}=0.38\right)$, and leaf length/width ratio $\left(r^{2}=0.62\right)$. Biochemical traits that play a role in the structural composition of vegetation, like lignin content $\left(r^{2}=0.98, r^{2}=0.54\right)$, concentration $\left(r^{2}=0.45\right)$ and cellulose content $\left(r^{2}=0.57\right.$, $r^{2}=0.49$ ), were found to be important by at least two of the analyses. Three other traits were important in at least one of the analyses: total biomass $\left(r^{2}=0.56\right)$, leaf $\mathrm{C} / \mathrm{N}$ ratio $\left(\mathrm{r}^{2}=0.99\right)$, and cellulose concentration $\left(\mathrm{r}^{2}=0.76\right)$. Redundancy analysis suggests that there is a large percentage $(52 \%)$ of the spectrum not explained by the PFTs measured in this study. However, spectral discrimination of functional groups, and even species, appears promising, mostly in the ultraviolet A part of the spectrum. This has interesting applications for mapping PFTs using remote sensing techniques, and therefore for estimating related ecosystem processes and services.
\end{abstract}

\section{Introduction}

Plant functional traits (PFTs) are those characteristics of a plant that may both respond to (response traits), and shape (effect traits) their environment (de Bello et al., 2010; Tilman, 2001). It has been suggested that PFTs are the key ecological attributes by which organisms and communities affect ecosystem processes and functioning (Díaz et al., 2007; Lavorel et al., 2007). For example, PFTs such as leaf dry matter content (LDMC) and specific leaf area (SLA) underpin soil fertility among others, whereas canopy size and architecture underpin climate and water regulation (Díaz et al., 2007). Since ecosystem processes are known to underpin ecosystem service provision, it is potentially possible to use PFTs to understand ecosystem service supply in ecosystems. Therefore mapping functional groups, species clustered according to
PFTs, could potentially be used in mapping ecosystem services. Plant functional traits also determine the optical properties of plants, which can have important implications for remote-sensing applications.

Canopy reflectance is determined by leaf, stem, and litter optical properties as well as attributes of canopy structure (Ali et al., 2015; Asner, 1998; Ross, 1981). There has been much research on trees at each of these scales, both deciduous (Asner and Martin, 2008; Baltzer and Thomas, 2005) and coniferous (de Marín et al., 2016), and less research on herbaceous species (Roelofsen et al., 2014). Herbaceous/ understory vegetation presents an interesting case due to lower coherence of chemistry-reflectance relationships as a result of often not being in direct sunlight (Roelofsen et al., 2014). There is a need for more research on the link between PFTs and reflectance spectra for other ecosystem types, such as shrublands, grasslands and wetlands,

\footnotetext{
* Corresponding author at: Ecosystem Management Research Group (ECOBE), Department of Biology, University of Antwerp, Universiteitsplein 1C, Wilrijk 2610, Belgium.

E-mail address: arebelo@sun.ac.za (A.J. Rebelo).

${ }^{1}$ AJR conceived the study, AJR performed data analysis, AJR wrote the manuscript and KJE, PM, BS contributed and edited it.
} 

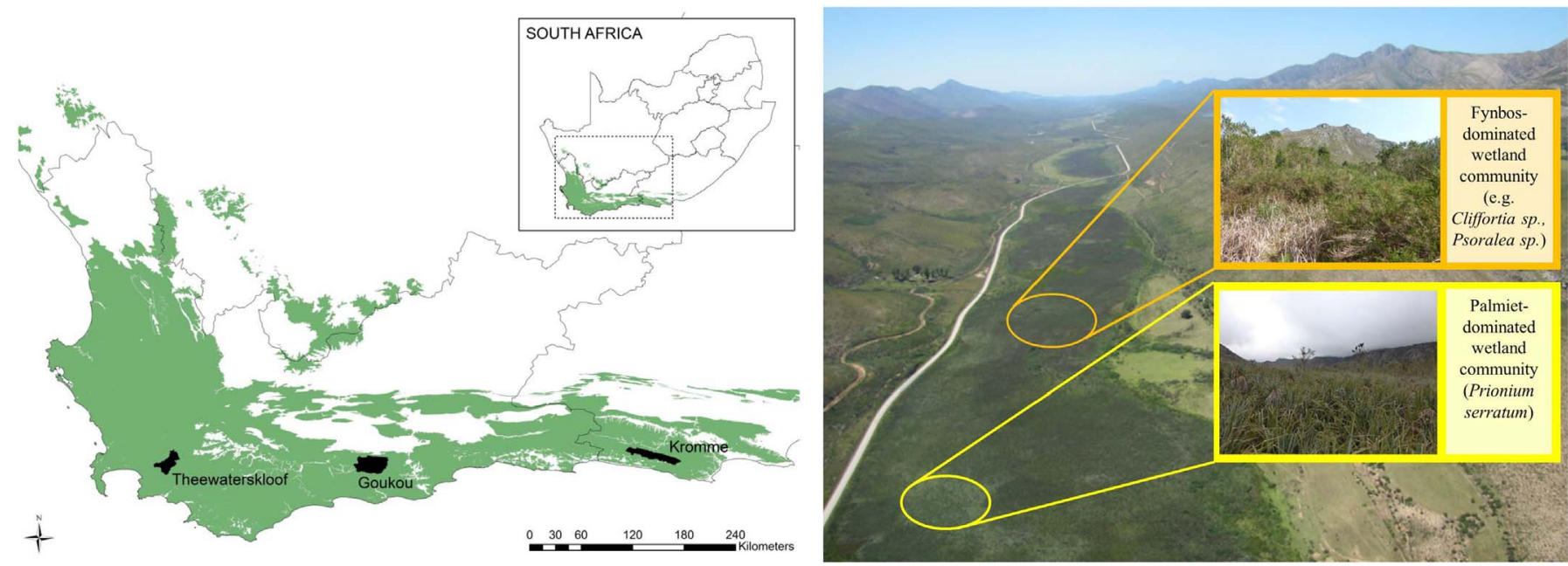

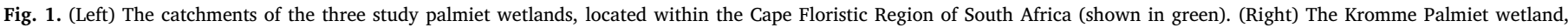
showing the patchy nature of the vegetation communities (light gray and dark green), with the two main plant communities indicated and described.

and particularly for African systems (Adam et al., 2010).

Leaves are optically interesting since plant species have differentially evolved unique properties to both optimise energy capture from the sun while minimizing sun damage and water loss. Leaf traits can influence their optical properties and the importance of specific traits in doing so varies within a species (Poona and Ismail, 2013), among growth forms (Klančnik et al., 2012) and between species (Klančnik et al., 2014b; de Marín et al., 2016). Different PFTs also affect different regions of the spectrum, for example the cuticle affects reflection and absorption in the visible and ultraviolet (UV) ranges (Krauss et al., 1997), whereas leaf thickness affects reflection and transmittance in the near-infrared (NIR) range (Knapp and Carter, 1998). Leaf pigments have been shown to affect the visible part of the spectrum (Asner and Martin, 2008; Klančnik et al., 2015a; Ustin et al., 2009; Zhang et al., 2008).

There has been much research on the use of leaf reflectance to predict PFTs, both biochemical (Carter and Spiering, 2002; Castro and Sanchez-Azofeifa, 2008; Klančnik et al., 2015b; de Marín et al., 2016; Roelofsen et al., 2014; Serbin et al., 2014; Van Cleemput et al., 2018; Zhang et al., 2008) and anatomical/morphological (Klančnik et al., 2015b; de Marín et al., 2016). At the leaf scale, specific leaf area (SLA), an index of leaf density, has been shown to be highly correlated $\left(\mathrm{r}^{2}=0.90\right)$ with the NIR and short-wave infrared (SWIR) part of the leaf spectrum for tropical forests (Asner and Martin, 2008), and coniferous trees (Lukeš et al., 2013), but poorly related $\left(r^{2}=0.26\right)$ for herbaceous species (Roelofsen et al., 2014). Leaf dry matter content (LDMC) is well correlated with reflectance $\left(r^{2}=0.67\right)$, even for herbaceous species (Roelofsen et al., 2014). Other studies have found biochemical traits to be more important for explaining spectral variation in aquatic plants, and morphological traits more important for terrestrial plants (Klančnik and Gaberšcik, 2016). Specifically trichome density and the thickness of the epidermis were most important in influencing the reflectance spectra of wetland species (Klančnik et al., 2015b). For aquatic plants, chlorophyll $a$ and b and SLA cumulatively explained $60 \%$ of the reflectance spectra (Klančnik et al., 2015b). More plastic PFTs, such as nutrients in plant tissues also affect reflectance (Asner and Martin, 2008; Baltzer and Thomas, 2005; Lukeš et al., 2013; Roelofsen et al., 2014; Serbin et al., 2014), as does tissue water content, particularly in the NIR region (Asner and Martin, 2008; Sims and Gamon, 2003).

It is important to establish the key PFTs influencing reflectance at various scales in different ecosystems, and whether functional groupings of species can be used to simplify this information (Roth et al., 2016). To date, most research of this nature has focussed on broad, conventional functional types or groups (e.g. growth form), and not on specific functional types derived from trait data. In addition, most research has been concentrated in Europe and the Americas. There is a need to examine relationships between traits and spectra in African ecosystems, particularly wetlands (Adam et al., 2010).

We analysed PFTs and spectra of dominant species in a South African palmiet wetland system to determine whether any relationships could be used to map functional groups. Wetlands are key ecosystems where understanding ecosystem function, and quantifying ecosystem services, are important for society (Rebelo et al., 2015). Wetlands are also extreme environments that have distinct community patterns, such as monospecific dominance in patches, making them interesting and important case study systems (Sieben, 2012). We ask two main research questions: can plant (or canopy)-level reflectance be used to predict morphological and biochemical PFTs in wetland vegetation? and; are wetland communities spectrally distinguishable (by functional groups, species)? If clear relationships exist between PFTs and spectra of these wetland species, then it may be possible to use hyperspectral methods to map ecosystem service hotspots in these wetlands.

\section{Methods}

\subsection{Study wetlands}

South African palmiet wetlands are small valley-bottom systems underlain by $0.5-8 \mathrm{~m}$ of peat and occurring throughout the Cape Floristic Region of South Africa, a biodiversity hotspot (Job, 2014; Nsor, 2007). Due to their position in important strategic water-providing catchments in South Africa (Nel et al., 2011), and their peat accumulation, they are thought to provide important ecosystem services to society (Rebelo et al., 2015). Palmiet wetlands are so named after the species that dominates them: Prionium serratum, or Palmiet, thought to be an ecosystem engineer (Sieben, 2012). However other plant communities occur within these wetlands, giving them a patchy appearance that may be possible to classify using hyperspectral remotesensing techniques. In this study, dominant species were determined from vegetation surveys in three palmiet wetlands: Theewaterskloof, Goukou and Kromme (Fig. 1). In places the wetlands have become invaded by alien weeds, such as Bramble (Rubus fruticosus), as well as trees such as Black Wattle (Acacia mearnsii). These palmiet wetlands typically occur at elevations of 100-400 masl, with mean annual precipitation ranging from $\pm 614 \mathrm{~mm}$ (Kromme) to $\pm 600-1000 \mathrm{~mm}$ (Goukou) to \pm 1600-2000 mm (Theewaterskloof) (Job, 2014; Midgley et al., 1994; Rebelo et al., 2006). 


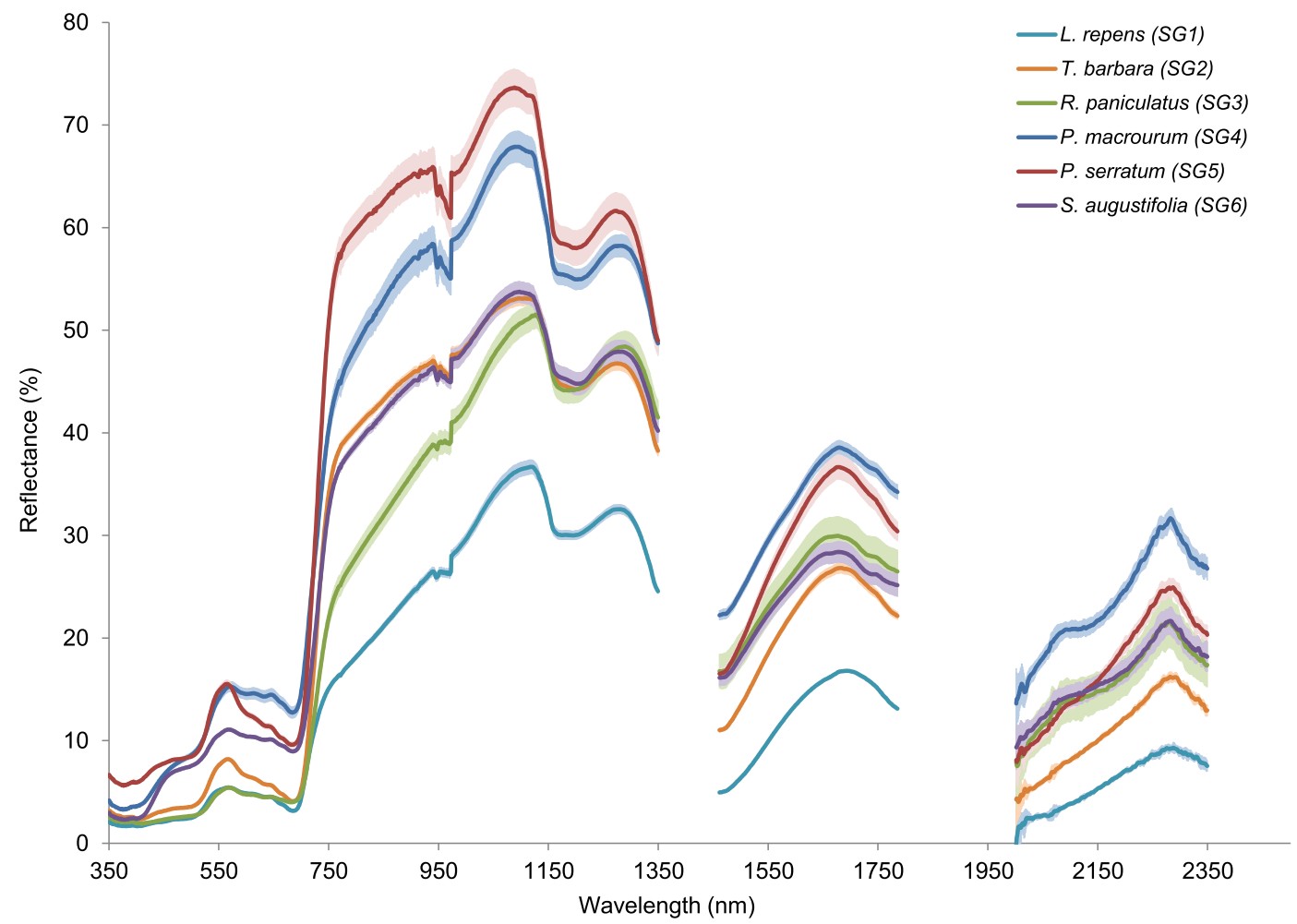

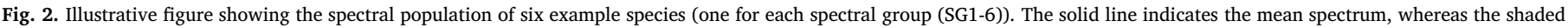
zone represents variation (standard deviation).

\subsection{Study design}

Species composition data were obtained from 39 plots in the three different palmiet wetlands. Plots were arranged on seven transects (100-200 m) along cross sections through the wetlands, with six plots $(3 \times 3 \mathrm{~m})$ placed between 20 and $50 \mathrm{~m}$ apart, yielding a total of 36 plots. In the Goukou wetland, three extra plots were added to fully capture variation in plant communities. Species and their relative abundances were recorded in each plot, using the Braun-Blanquet Scale (Mueller-Dombois and Ellenberg, 1974). Dominant species were defined as those making up $>25 \%$ cover in any plot. The resultant 22 species are listed in Table S1, Fig. S1. Ten mature specimens from each dominant species were collected from their wetland of origin for measurement of PFTs at the respective field station or in the lab (depending on the trait). Traits were collected once for each species from random specimens in the field (maximum abundance approach, Carmona et al., 2015). Extra specimens were collected from one of the three sites for each species (Table S1).

\subsection{Plant functional traits}

We measured 23 PFTs, each selected as they were predicted to have a link to at least one wetland ecosystem service (Table S2). Definitions and methods for the measurements of each PFT are given in Table S3; and for all commonly used PFTs we used the standardised protocol for measurements (Pérez-Harguindeguy et al., 2013). Of the PFTs measured, 16 were morphological/anatomical, and seven were biochemical in nature (Table S3). For biochemical traits, samples were cleaned, dried at $70{ }^{\circ} \mathrm{C}$ for $48 \mathrm{~h}$, ground and homogenised using a mill to $0.5 \mathrm{~mm}$ particles. Total carbon and total nitrogen were determined by total combustion of $5 \mathrm{mg}$ of each sample on a Flash $2000 \mathrm{CN}$-analyzer (Thermo Fisher Scientific). To determine plant silicon content, we used a procedure for extracting biogenic silica (Schoelynck et al., 2010), which involved incubating a $25 \mathrm{mg}$ sample of dried plant material in a $0.1 \mathrm{~m} \mathrm{Na}_{2} \mathrm{CO}_{3}$ mixture which was placed in a water bath at $80^{\circ} \mathrm{C}$ for
$4 \mathrm{~h}$. This dissolved biogenic silica was then spectrophotometrically analysed on a Thermo IRIS inductively coupled plasmaspectrophotometer (ICP; Thermo Fisher, Franklin, MA, USA). Plant lignin and cellulose content were measured using the Van Soest method (Van Soest, 1963). Summary statistics are shown for each of the continuous PFTs in Table S4.

\subsection{Reflectance measurements}

Plant canopy spectra were measured in the field in November 2015 (spring) under clear sky conditions within $2 \mathrm{~h}$ of local solar noon. Phenology has been shown to be valuable in discriminating wetland species (e.g. reed beds) and spring is the season in which interspecific phenological distinctions are generally at their greatest (Ouyang et al., 2013; Tuominen and Lipping, 2016). All reflectance measurements were taken with a portable ASD Fieldspec Pro (ASD Inc., Boulder, USA). The probe was held at a constant distance of $60 \mathrm{~cm}$ above the surface $\left(25^{\circ} \mathrm{FOV}\right.$; diameter $\left.26.59 \mathrm{~cm}\right)$, keeping the sensor perpendicular to the angle of the sun. Live (wet) specimens from each species were arranged on a large matt black (non-reflective: uniform $<5 \%$ reflectance across the $350-2500 \mathrm{~nm}$ range) surface $(1.5 \times 2 \mathrm{~m})$, with leaves facing upwards (adaxial surface up) where possible. This measurement set-up allowed us to measure the reflectance of individual plant species without background contamination originating from soil or other plant species. This set-up thus allowed us to make a one-on-one comparison between reflectance and PFTs. It is acknowledged that the spectral effects of 3D canopy structure (i.e. volume scattering effects) were not fully captured with this set-up. Since this study focussed primarily on leaf traits, this is not expected to present any problems.

Twenty spectral signatures were collected for each species. There were two cases where data had to be excluded due to equipment problems (see Table S1 for details). Between readings for each species, the ASD was optimised using a spectralon (Spectralon ${ }^{\circledR}$, Labsphere, North Sutton, USA) and white reference measurements were captured. Spectra were collected over the range of $350-2500 \mathrm{~nm}$ with $1 \mathrm{~nm}$ intervals. ASD 
binary files were first converted to ASCII reflectance files using ViewSpecPro and subsequently post-processed to remove data in the water absorption bands at $1350-1460 \mathrm{~nm}$ and $1790-2000 \mathrm{~nm}$ as well as noise at $2350-2500 \mathrm{~nm}$. A sub-set of the spectral measurements (one species from each of the six spectral groups; Table S8) and their variance (standard deviation) are displayed (Fig. 2).

\subsection{Analysis}

Analysis was carried out in two stages; first, plant-level reflectance was assessed for use in predicting morphological and biochemical PFTs, and second, wetland communities were assessed to determine whether they are spectrally distinguishable, and to what level (functional groups, species). Dimension reduction methods were applied in the first two analyses, as opposed to preservation of the original spectral resolution, so as to improve compatibility when scaling-up to hyperspectral reflectance measurements; a possible next step (e.g. see Roth et al., 2015).

\section{(i) Predicting morphological and biochemical traits from reflectance}

To determine whether it was possible to predict morphological and biochemical PFTs from plant reflectance spectra, we first used an approach similar to that of Knapp and Carter (1998) to relate spectra to PFTs by reducing the spectrum to four average reflectance values: visible $(400-700 \mathrm{~nm})$, NIR (700-1000 nm), SWIR (1000-2349 nm), and the total measured spectra $(350-2349 \mathrm{~nm})$. Simple regression analyses in $\mathrm{R}$ were used to determine the relationships between the averaged spectra and PFTs. Second, we performed a redundancy analysis (RDA) using the "Vegan" package in $\mathrm{R}$ to determine whether the reflectance spectra (response variables) could be explained by various PFTs (explanatory variables). For this analysis, the reflectance spectra were divided into 11 categories and averaged: the four categories listed above (visible, NIR, SWIR and total) as well as part of the ultraviolet A (UV-A) $(320-399 \mathrm{~nm})$, violet $(400-424 \mathrm{~nm})$, blue $(425-491 \mathrm{~nm})$, green $(492-575 \mathrm{~nm})$, yellow $(576-585 \mathrm{~nm})$, orange $(586-647 \mathrm{~nm})$, and red $(648-699 \mathrm{~nm})$. All variables were standardised for the analysis, and categorical PFT data were excluded. Forward selection of explanatory variables was used to avoid co-linearity between variables (threshold: $\mathrm{r}^{2}>0.7$ ). Variable inflation factors (VIFs) of $>10$ were used to exclude other collinear variables to obtain the most parsimonious RDA. The significance of the RDA was assessed using an ANOVA-like permutation test for RDA in R, with 1000 permutations (Legendre et al., 2011).

Lastly we performed a partial least squares regression (PLSR) using the "pls" package (Mevik and Wehrens, 2007) and "autopls" code (Feilhauer et al., 2010) in R to determine which PFTs could be predicted from the reflectance spectra. The advantage of PLSR over other types of regression is its ability to deal with a high number of predictors (in this case spectral bands) relative to a low number of observations (i.e. each PFT) as well as handle collinearity of these predictors. We performed PLSR for each of the 14 measured continuous PFTs, which were log transformed, using the entire spectrum, as well as using parts of the spectrum: UV-A, visible, NIR and SWIR. Collinearity of spectral bands is dealt with by transferring information content to independent latent variables (lv) which are optimised to represent the response variable. In each model, the number of latent variables was chosen so as to minimise the root mean square error (RMSE) using leave-one-out (LOO) cross-validation. Each ordination axis was modelled separately (calibrated) and then validated, and regression coefficients were calculated in each case, and predictors are left out iteratively until an optimum was reached. Backward selection of predictors was used to further optimise the model by a combination of removing correlated bands and jack-knifing. All other settings were left at the default, following the method of Feilhauer et al. (2010). Model accuracy is expressed by both the root mean square error (RMSE) and the coefficient of determination $\mathrm{r}^{2}$ which compares observed and predicted values for the calibration and validation phases.

\section{(ii) Discriminating wetland communities}

To determine at what level wetland communities are spectrally distinguishable, we compared the effectiveness of discriminating individual species with that of discriminating functional groups. We determined functional and spectral groups of the 22 dominant species using two-step cluster analysis in SPSS (SPSS, 2001), which is able to handle both categorical and continuous data. All variables were standardised and the log-likelihood distance measure was applied for PFTs, and the Euclidean distance measure for spectra. The threshold for number of functional and spectral groups was determined using a $\mathrm{K}$ means partitions comparison and Calinski criterion, as well as a Scree plot in R (Table S7). The importance of various PFTs in influencing the functional groups was assessed using a predictor analysis in SPSS. To assess how well functional groups and species could be discriminated, we used two approaches.

Firstly we compared functional groups and species to spectral groups generated using reflectance spectra, in a confusion matrix and assessed coherence. We did this by estimating "spread" of functional groups throughout the spectral groups. If each functional group corresponded with its distinct spectral group, we would expect to see low spread in the confusion matrix, i.e. only 6 out of the 36 blocks in the grid would be occupied ( 6 blocks occupied is the minimum). However a poor agreement (high spread), could mean that 22 of the 36 blocks were occupied ( 22 species is the maximum). Therefore discrimination accuracy (DA) was calculated by expressing the number of occupied blocks scaled between 0 and 16 (n) as a percentage, and inverting it; i.e.: $\mathrm{DA}=100-(100 \mathrm{n} / 16)$. Secondly the spectral separability between each functional group and among species was calculated using the M-Statistic for four parts of the spectrum: visible (400-700 nm), NIR (700-1000 nm), short-wave infrared (SWIR) $(1000-2349 \mathrm{~nm})$, and the total measured spectra $(350-2349 \mathrm{~nm})$. The M-Statistic is calculated by dividing the difference of the means of spectra of the two species or functional groups being compared, by the sum of their standard deviations (Kaufman and Remer, 2002). In the case of species, each species was compared with an average of all other species. A value of $M<1$ signifies that the distributions significantly overlap and the ability to discriminate the two groups is poor, whereas a value of $M>1$ signifies that there is little overlap and the ability to discriminate the two groups is good.

\section{Results}

\subsection{Predicting morphological and biochemical PFTs from spectral reflectance}

Only four PFTs showed reasonably strong relationships with various parts of the spectrum. Biochemical traits such as cellulose and lignin content were reasonably well correlated with the NIR part of the spectrum (Fig. 3; Table S5). Morphological traits, such as leaf area and mass, on the other hand correlated more weakly with the total reflectance spectrum.

An RDA analysis suggested that four PFTs were most important in explaining reflectance spectra of the 22 dominant wetland species investigated: leaf area, the leaf length/width ratio, SLA and lignin concentration (Fig. 4). Together these PFTs explained $48 \%$ of the variation in the spectra. Of these PFTs, only one was biochemical, suggesting that of the PFTs measured, morphological traits exerted more influence on the reflectance spectra. Leaf area and leaf length/width ratio were strongly positively correlated with reflectance, whereas SLA and lignin concentration were weakly negatively correlated.

When considering the entire reflectance spectrum, only one of the 14 continuous PFTs investigated using PLSR was predicted from the 


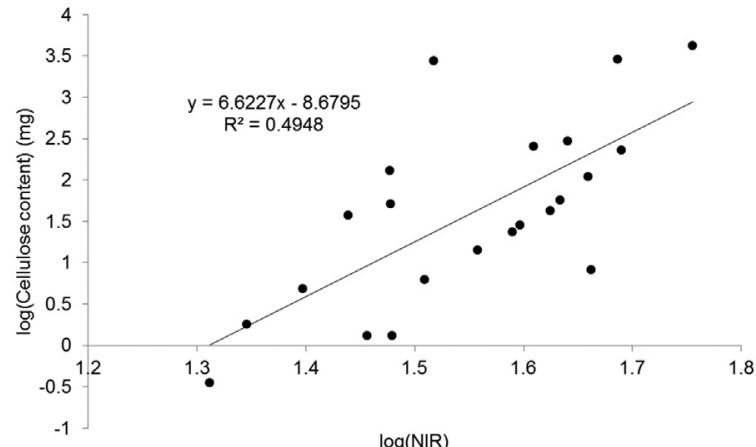

$\log (\mathrm{NIR})$

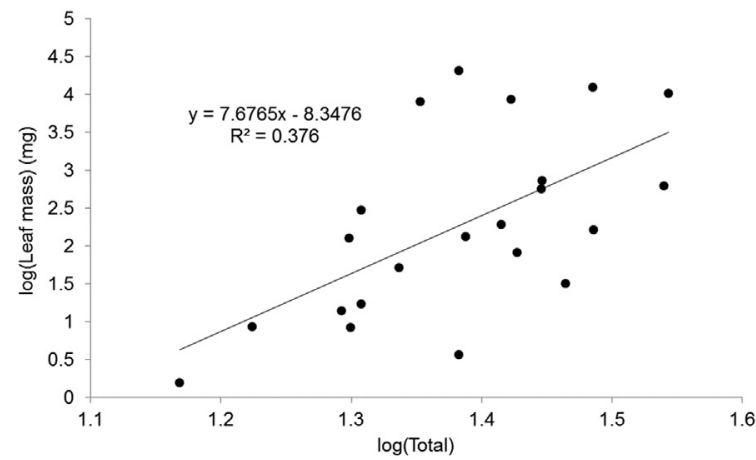

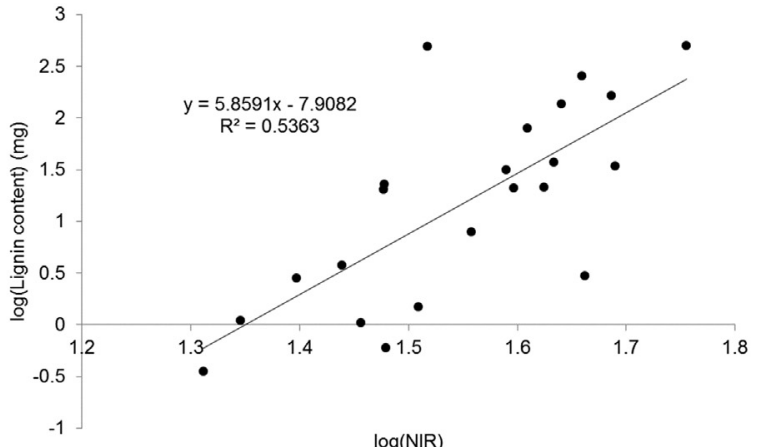

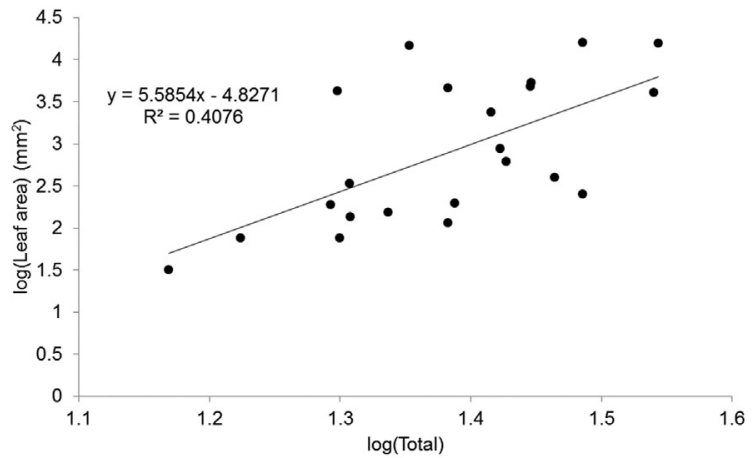

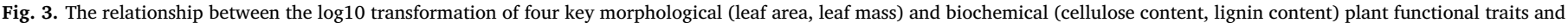
the $\log 10$ transformation of averaged sections of the reflectance spectra (NIR: 700-1000 nm, Total: $350-2349 \mathrm{~nm}$ ) for 22 South African wetland species.

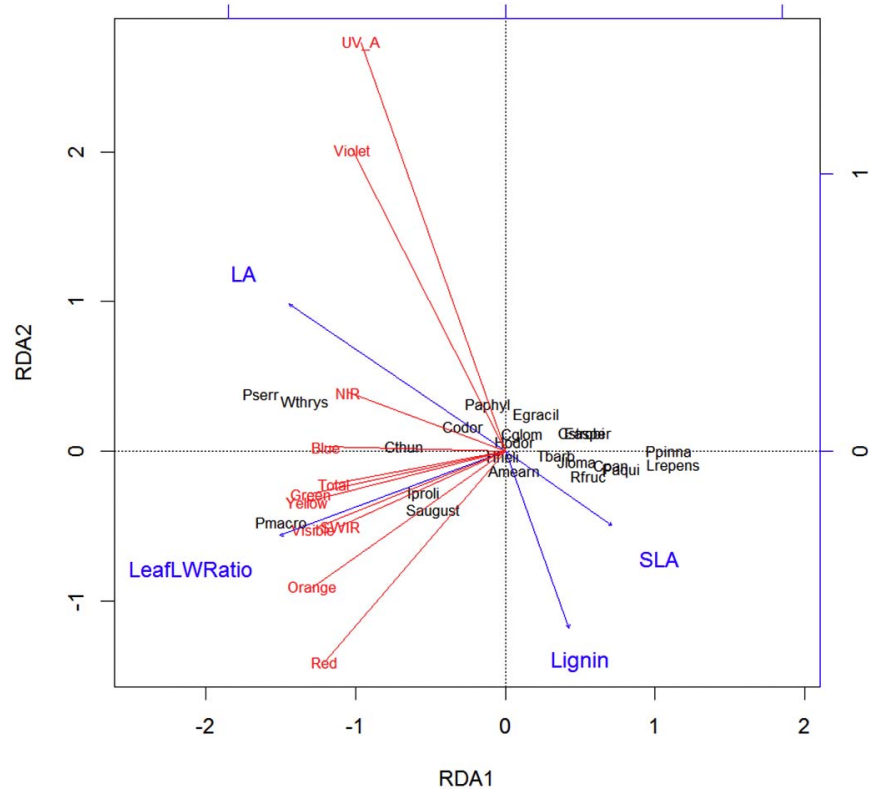

Fig. 4. The RDA plot presenting the strength of associations between anatomical and biochemical parameters and different regions of the reflectance spectra for 22 South African wetland species. Eigenvalues for the first two axes were 4.77 and 0.41 respectively, and only the first axis was significant. Species abbreviations are given in black (see Table X3 for full names). The various regions of the spectrum are given in red. Abbreviations for the most important plant functional traits influencing the model are given in blue: LA: leaf area $\left(\mathrm{mm}^{2}\right)$, SLA: specific leaf area $\left(\mathrm{mm}^{2} / \mathrm{mg}\right)$, LeafLWRatio: leaf length-width ratio and Lignin: lignin concentration (\%). (For interpretation of the references to colour in this figure legend, the reader is referred to the web version of this article.)

reflectance spectra with high accuracy, and this was lignin content $\left(r_{\text {cal }}^{2}=0.98\right)$ (Table 1, Fig. 5). However this model also had the highest number of latent variables (7), suggesting a complex, non-linear
Table 1

Model performance parameters for partial least squares regression (PLSR) of predicting plant functional traits from reflectance spectra of 22 South African wetland species for the total measured spectra. Abbreviations: nlv is the number of latent variables, $r^{2}$, the coefficient of determination, is given for model calibration and validation, as is RMSE: the root mean square error. Shaded cells show $\mathrm{r}^{2}$ (calibration) values of $>0.40$. Results for the four separate parts of the spectra (UV-A, visible, NIR, SWIR) are shown in Table S6.

\begin{tabular}{|c|c|c|c|c|c|c|}
\hline & Plant functional traits & nlv & $r_{\text {cal }}^{2}$ & $r^{2}$ val & $\mathrm{RMSE}_{\text {cal }}$ & $\operatorname{RMSE}_{\text {val }}$ \\
\hline \multirow{7}{*}{ Morphological } & Shoot length & 2 & 0.16 & -0.42 & 0.47 & 0.61 \\
\hline & Stem diameter & 2 & 0.16 & -0.08 & 0.66 & 0.75 \\
\hline & Total biomass & 2 & 0.16 & -0.06 & 1.26 & 1.42 \\
\hline & Leaf length/width ratio & 2 & 0.31 & 0.01 & 0.50 & 0.60 \\
\hline & Leaf dry mass & 2 & 0.43 & 0.16 & 0.90 & 1.09 \\
\hline & Leaf area & 2 & 0.39 & 0.20 & 0.65 & 0.74 \\
\hline & Specific leaf area (SLA) & 2 & 0.19 & -0.22 & 0.57 & 0.70 \\
\hline \multirow{7}{*}{ Biochemical } & Leaf $\mathrm{C} / \mathrm{N}$ ratio & 5 & 0.61 & 0.35 & 0.14 & 0.17 \\
\hline & Si concentration & 2 & 0.25 & -0.05 & 0.61 & 0.72 \\
\hline & Si content & 2 & 0.37 & -0.30 & 1.09 & 1.56 \\
\hline & Cellulose concentration & 2 & 0.41 & 0.22 & 0.09 & 0.10 \\
\hline & Cellulose content & 1 & 0.57 & 0.49 & 0.72 & 0.77 \\
\hline & Lignin concentration & 1 & 0.38 & 0.23 & 0.27 & 0.30 \\
\hline & Lignin content & 7 & 0.98 & 0.91 & 0.13 & 0.27 \\
\hline
\end{tabular}

relationship (high information content). Leaf $\mathrm{C} / \mathrm{N}$ ratio was predicted with average accuracy $\left(r_{\text {cal }}^{2}=0.61\right.$ ), and three other PFTs (cellulose content, concentration and leaf dry mass) were weakly predictable from the reflectance spectra $\left(r_{\text {cal }}^{2}=0.57, r_{\text {cal }}^{2}=0.41\right.$, and $r_{\text {cal }}^{2}=0.43$ respectively). The UV-A was the best part of the spectrum in predicting both biochemical and morphological PFTs for these wetland species in 

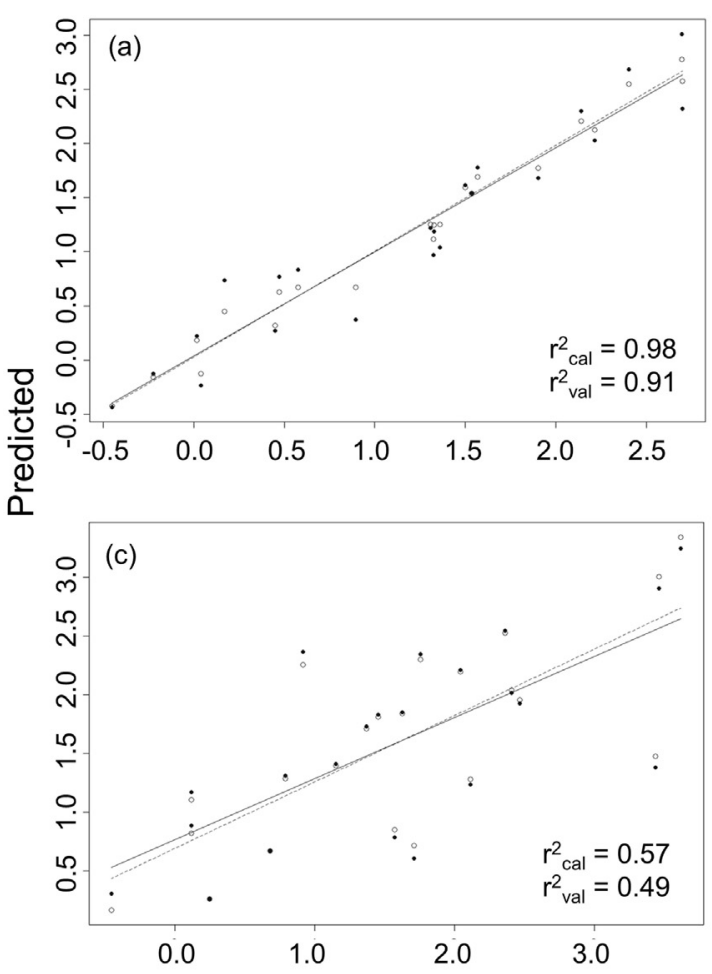
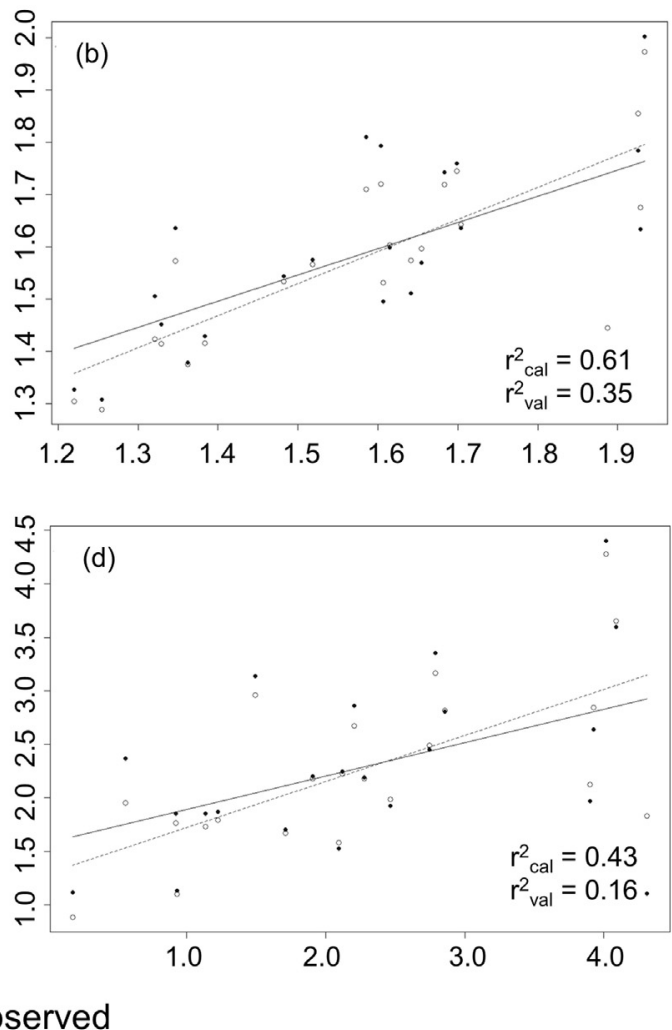

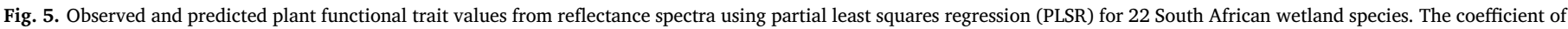

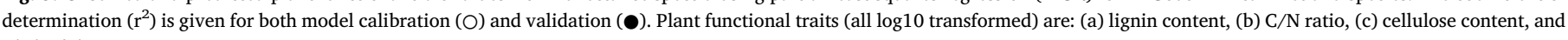
(d) leaf dry mass.

the season studied (spring) (Table S6). All other parts of the spectrum were unimportant in predicting morphological traits, with the exception of the SWIR for predicting total biomass. In predicting biochemical traits: the visible, NIR and SWIR parts of the spectrum were important in predicting lignin and cellulose, and the visible part of the spectrum was additionally important for predicting $\mathrm{C} / \mathrm{N}$ ratios (Table S6).

Overall, the results suggest that there are ten PFTs of those measured that influence optical properties to some degree: five morphological traits (leaf area, leaf mass, SLA, leaf length-width ratio, total biomass) and five biochemical traits (lignin concentration, lignin content, cellulose concentration, cellulose content, $\mathrm{C} / \mathrm{N}$ ratio).

\subsection{Discriminating wetland communities}

For both functional and spectral groups, K-means partitions and scree plots indicated that the optimal number of groupings was six. For functional groups, species were relatively well spread, with an average of four ( \pm 1.3 ) species per group (Table S7). Spectral groups were less well spread, with one large group containing nine species (Table S8). The ten most important PFTs driving functional groups were (in decreasing order of importance): cellulose content, leaf area, leaf orientation, leaf type, leaf length-width ratio, lignin content, $\mathrm{C} / \mathrm{N}$ ratio, rooting type, woodiness and clonal strategy. Functional groups seem to make sense ecologically, and the six groups can be broadly described as: (1) woody species with small simple leaves with medium surface area and medium cellulose content, (2) woody species with larger simple leaves with smaller surface area and low cellulose content, (3) ferns; with pinnatifid leaves (low leaf area), and low cellulose content, (4) less woody species with no true leaves, and medium cellulose content, (5), herbaceous species (non-woody) with long broad leaves (high area) but low cellulose content, and (6) herbaceous species (non-woody) with long broad leaves (high area) but high cellulose content. The two most important PFTs: cellulose content and leaf area, correspond well with those shown to be predictable from the reflectance spectrum.

The ten most important reflectance spectra driving spectral groupings were all in the range $530-615 \mathrm{~nm}$, the visible (green, yellow, orange) part of the electromagnetic spectrum, suggesting that photosynthetic pigments are the most important PFTs determining spectral separability of species. Interestingly spectral group 5 corresponds well to functional group 6, containing two species in common: the ecosystem engineer $P$. serratum and Wachendorfia thyrsiflora (both broad-leaved species).

A confusion matrix comparing functional and spectral groups suggests that there is not high coherence between functional groups and spectral groups, with $37.5 \%$ overall discrimination accuracy (Table 2). The large spectral group (1), for example, is composed of 6 different functional groups. Specific functional groups ( 3 and 6 ) are marginally distinguishable spectrally (functional groups split into only two spectral groups in each case).

Table 2

Confusion matrix displaying the spectral separability of functional groups. The numbers in the matrix represent number of species.

\begin{tabular}{|c|c|c|c|c|c|c|c|}
\hline & & \multicolumn{7}{|c|}{ Spectral group } \\
\hline \multirow{4}{*}{ Functional } & & 1 & 2 & 3 & 4 & 5 & 6 \\
\hline \multirow{4}{*}{ group } & 1 & 2 & 2 & & & & \\
\cline { 2 - 8 } & 2 & 2 & 2 & 1 & & & 1 \\
\cline { 2 - 8 } & 4 & 2 & & 1 & & & 1 \\
\cline { 2 - 8 } & 5 & 1 & & & 1 & & 1 \\
\hline & 6 & 1 & & & & 2 & \\
\hline
\end{tabular}


Table 3

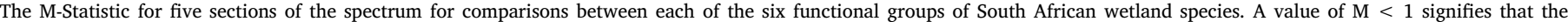

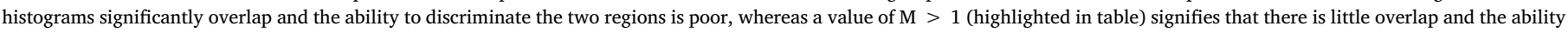
to discriminate the two regions is good.

\begin{tabular}{|l|l|l|l|l|l|}
\hline Functional & UV-A & Visible & NIR & SWIR & Total \\
group & $(350-400 \mathrm{~nm})$ & $(400-700 \mathrm{~nm})$ & $(700-1000 \mathrm{~nm})$ & $(1000-2349 \mathrm{~nm})$ & $(350-2349 \mathrm{~nm})$ \\
\hline FG1-2 & 0.61 & 0.32 & 0.07 & 0.04 & 0.02 \\
\hline FG2-3 & 1.70 & 0.47 & 0.21 & 0.04 & 0.01 \\
\hline FG3-4 & 2.20 & 0.33 & 0.21 & 0.07 & 0.02 \\
\hline FG4-5 & 0.91 & 0.63 & 0.30 & 0.13 & 0.12 \\
\hline FG5-6 & 3.10 & 0.12 & 0.37 & 0.02 & 0.05 \\
\hline FG1-3 & 2.30 & 0.18 & 0.14 & 0.00 & 0.01 \\
\hline FG1-4 & 0.09 & 0.17 & 0.07 & 0.07 & 0.04 \\
\hline FG1-5 & 1.05 & 0.82 & 0.22 & 0.20 & 0.15 \\
\hline FG1-6 & 4.50 & 0.96 & 0.56 & 0.21 & 0.20 \\
\hline FG2-4 & 0.65 & 0.14 & 0.01 & 0.03 & 0.01 \\
\hline FG2-5 & 1.56 & 0.53 & 0.30 & 0.16 & 0.13 \\
\hline FG2-6 & 5.00 & 0.66 & 0.65 & 0.17 & 0.18 \\
\hline FG3-5 & 2.96 & 0.92 & 0.06 & 0.19 & 0.13 \\
\hline FG3-6 & 6.28 & 1.06 & 0.40 & 0.20 & 0.18 \\
\hline FG4-6 & 4.17 & 0.77 & 0.65 & 0.15 & 0.17 \\
\hline
\end{tabular}

Table 4

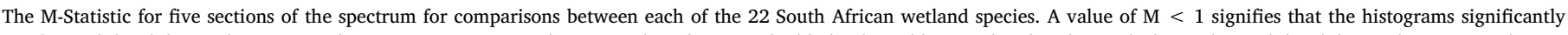

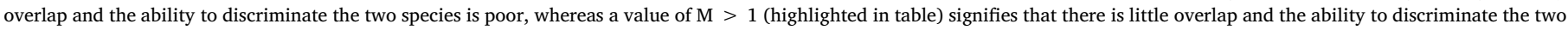
species is good. In each case the species listed was compared with all other species together.

\begin{tabular}{|c|c|c|c|c|c|}
\hline Species & $\begin{array}{l}\text { UV-A (350- } \\
400 \mathrm{~nm})\end{array}$ & $\begin{array}{l}\text { Visible (400- } \\
700 \mathrm{~nm})\end{array}$ & $\begin{array}{l}\text { NIR }(700- \\
1000 \mathrm{~nm})\end{array}$ & $\begin{array}{l}\text { SWIR (1000- } \\
2349 \mathrm{~nm})\end{array}$ & $\begin{array}{l}\text { Total (350- } \\
2349 \mathrm{~nm})\end{array}$ \\
\hline Acacia mearnsii & 2.40 & 0.16 & 0.44 & 0.10 & 0.10 \\
\hline Carpha glomerata & 0.83 & 0.07 & 0.24 & 0.09 & 0.08 \\
\hline Cliffortia odorata & 1.25 & 0.04 & 0.45 & 0.14 & 0.13 \\
\hline Cliffortia strobilifera & 0.19 & 0.45 & 0.50 & 0.20 & 0.17 \\
\hline Cyperus thunbergii & 1.58 & 0.50 & 0.22 & 0.13 & 0.11 \\
\hline Elegia asperiflora & 0.48 & 0.52 & 0.27 & 0.21 & 0.15 \\
\hline Epischoenus gracilis & 1.46 & 0.13 & 0.44 & 0.21 & 0.17 \\
\hline $\begin{array}{l}\text { Helichrysum } \\
\text { helianthemifolium }\end{array}$ & 0.03 & 0.07 & 0.42 & 0.04 & 0.02 \\
\hline $\begin{array}{l}\text { Helichrysum } \\
\text { odoratissimum }\end{array}$ & 1.14 & 0.15 & 0.81 & 0.22 & 0.20 \\
\hline Isolepis prolifera & 0.60 & 0.31 & 0.35 & 0.26 & 0.18 \\
\hline Juncus lomatophyllus & 1.37 & 0.29 & 0.61 & 0.19 & 0.18 \\
\hline Laurembergia repens & 4.67 & 0.86 & 1.11 & 0.43 & 0.38 \\
\hline Psoralea aphylla & 2.25 & 0.07 & 0.34 & 0.03 & 0.05 \\
\hline Pteridium aquilinum & 4.42 & 0.75 & 0.04 & 0.14 & 0.10 \\
\hline Pennisetum macrourum & 0.78 & 0.90 & 0.63 & 0.39 & 0.30 \\
\hline Psoralea pinnata & 3.44 & 1.09 & 0.96 & 0.33 & 0.31 \\
\hline Prionium serratum & 6.20 & 0.97 & 0.93 & 0.29 & 0.28 \\
\hline Restio paniculatus & 3.15 & 0.85 & 0.38 & 0.07 & 0.02 \\
\hline Rubus fruticosus & 3.99 & 0.68 & 0.27 & 0.04 & 0.04 \\
\hline Searsia angustifolia & 2.17 & 0.52 & 0.12 & 0.08 & 0.07 \\
\hline Todea barbara & 1.43 & 0.37 & -0.15 & 0.03 & 0.01 \\
\hline Wachendorfia thyrsiflora & 4.70 & 0.78 & 0.63 & 0.17 & 0.18 \\
\hline
\end{tabular}

According to the calculated spectral separability index (M-Statistic), most of the functional groups are best discriminated in the UV-A part of the spectrum (Table 3). The only exception is functional group 3 (ferns) and 6 (broad-leaved species) which are additionally separable using the visible part of the spectrum. Only two of the functional groups were problematic to separate, and these were functional groups 1 and 4 . Sixteen out of the 22 species were highly spectrally distinguishable, mainly in the UV-A part of the spectrum (Table 4). Only three species were a challenge to discriminate from the rest: Cliffortia strobilifera, Elegia asperiflora, and Helichrysum helianthemifolium. Laurembergia repens was additionally spectrally distinct from the other species in the NIR part of the spectrum, and Psoralea pinnata in the visible.

\section{Discussion}

Clear relationships were established between wet-material reflectance spectra and certain PFTs of 22 dominant South African wetland species, both herbaceous and woody. These relationships are relatively strong considering that reflectance spectra and PFTs were measured on different specimens, suggesting that using reflectance spectra to characterise PFTs in these systems is feasible. This presents significant opportunities for PFT prediction or mapping in these wetland systems, using imaging spectroscopy or hyperspectral remote sensing techniques. 


\subsection{Relationships between leaf traits and spectra}

There was some commonality between the results of the three approaches used to explore PFT/reflectance relationships: regressions, RDA and PLSR. However, no PFT was found to be consistently related to reflectance spectra in all three analyses. Of the ten traits found to be relatable to the spectrum, five were morphological (total biomass, leaf length/width ratio, specific leaf area, leaf dry mass, leaf area) and five biochemical (leaf $\mathrm{C} / \mathrm{N}$ ratio, cellulose concentration, cellulose content, lignin concentration, lignin content). Seven PFTs were found to relate to the spectrum in at least two independent analyses: four morphological traits (leaf length/width ratio, specific leaf area, leaf dry mass, leaf area) and three biochemical traits (cellulose content, lignin concentration and lignin content).

Leaf area was strongly, positively correlated with reflectance spectra, though according to the regression results the entire spectrum was important - no particular region stood out. Specific leaf area was found to be an important PFT by the RDA and PLSR methods. For the RDA, SLA showed a weak negative relationship with reflectance spectra, especially in the NIR region, whereas for the PLSR, SLA was reasonably well predicted by the UV-A part of the spectrum. Other studies, for example on aquatic and wetland plants, have shown SLA to be strongly positively correlated with reflectance spectra (Klančnik et al., 2014a, Klančnik et al., 2015b). One possible reason for this weak relationship between SLA and reflectance spectra in the NIR region could be the loss of 3D information as a result of our measurement setup (Ali et al., 2015; Ross, 1981). On the other hand, other studies have successfully found relationships between spectra and traits such as SLA and LDMC using only leaf level spectra, without any information on plant architecture/canopy structure (Ali et al., 2015).

Structural components, lignin and cellulose content, were also shown to be important by two analyses (the regressions and PLSR), corresponding especially with the NIR portion of the spectrum. A study on northern temperate and boreal tree species identified lignin and cellulose to be PFTs that scale well in reflectance-trait models (leaf to canopy scale (Serbin et al., 2014)). Three other PFTs were also found to be important by two of the three analyses: leaf mass, leaf length/width ratio, and lignin concentration. Another three PFTs were found to be important by only one of the three analyses: total biomass, cellulose concentration and the $\mathrm{C} / \mathrm{N}$ ratio. Overall the RDA analysis suggests that there is a large fraction (over half) of the variation in the spectra not explained by the PFTs measured in this study. This has implications for future ecological studies with remote-sensing application: important PFTs to measure may include photosynthetic pigments, or correlates, such as leaf thickness. There have been several studies investigating the importance of biochemical leaf traits in explaining reflectance spectra specifically. These studies suggest that chlorophyll $a$ and $b$, together with SLA account for most of the spectral variability in aquatic plants (Klančnik et al., 2014a), as well as trichome length, leaf mass and anthocyanin content per dry mass (Klančnik et al., 2012). For wetland species, total mesophyll and spongy tissue thickness were found to be important as well as leaf prickle hair properties and epidermal thickness for monocots, and leaf thickness and SLA for dicots (Klančnik and Gaberšcik, 2016). Other factors such as epiphyton and silicified structures were also shown to affect reflectance spectra in macrophytes (Klančnik et al., 2014b; Klančnik et al., 2015a).

\subsection{Predicting leaf traits from spectra}

Overall biochemical traits were more successfully predicted from reflectance spectra than morphological traits. Expressing biochemical parameters per leaf mass (content rather than concentration) improved its predictive ability from the reflectance spectrum, similar to findings of another study with expressing foliar nutrients per leaf area (Roelofsen et al., 2014). Measuring only leaf spectra, they found weak relationships between morphological properties of herbaceous species, such as SLA, but stronger relationships for particular biochemical traits, such as leaf nitrogen content. In contrast, LDMC, which we did not measure, was found to be well predicted from reflectance and transmittance spectra (Roelofsen et al., 2014). Since our study, as well as Roelofsen et al. (2014), also only measured leaf/stem spectra, the lack of 3D information in our spectral measurements may be a cause for the weak relationships found between spectra (particularly in the NIR) and certain morphological traits relating to plant size or growth form, such as biomass, stem diameter and plant height (Ali et al., 2015; Ross, 1981).

Leaf reflectance for forest (top of canopy) species however, were strongly related to morphological traits. For example SLA, or its inverse (leaf mass per area), were well predicted by reflectance spectra for forest species, with the correlation co-efficient ranging from 0.79 to 0.91 (Asner et al., 2011; Asner and Martin, 2009; Asner and Martin, 2008; Serbin et al., 2014). For carbon containing compounds, such as cellulose, lignin and photosynthetic pigments, Asner et al. (2011) were able to successfully project leaf spectra to the canopy level. This suggests that it may well be possible to map these traits at an ecosystem scale using remote-sensing techniques. Scaling-up these relationships from leaf level measurements to canopy level, using airborne or satellite sensors, is known to present challenges (Asner and Martin, 2008; Li et al., 2014), particularly in wetlands (Adam et al., 2010). This is largely due to the typically high species richness, spatial heterogeneity (leading to background contamination) and complex 3D canopy structure of wetlands (Adam et al., 2010; Silva et al., 2008). It is also a challenge to find a sensor that covers the necessary area, but has high enough spectral, spatial and temporal resolutions (Adam et al., 2010). However, palmiet wetlands may be an ideal study ecosystem for this, due to their small size and low spatial heterogeneity (dominated mainly by dense stands of one species, $P$. serratum).

This study investigated relatively few plant species (22) relative to previous studies (e.g. 35 in Roelofsen et al. (2014) and hundreds of samples in other studies (Asner et al., 2011; Serbin et al., 2014)). The reason for this low number of species is the high level of monospecific dominance in these wetland communities. A low number of species limits the power of the PLSR models, therefore in more diverse systems including more species may reveal more clear relationships. Overall our results suggest that it may be possible to use spectroscopic methods to quantify certain PFTs, including certain morphological traits (leaf area), structural components (lignin, cellulose) and nutrients ( $\mathrm{C} / \mathrm{N}$ ratio) in South African wetlands, based on information from dominant species. However it is also possible that species, or functional groups, should be distinguishable within wetland communities, based on the findings that certain PFTs are related to reflectance spectra, despite intra-specific variation.

\subsection{Applications for using PFT-reflectance spectra relationships to map ecosystem service hotspots}

It appears feasible to discriminate dominant South African wetland species using reflectance spectra. It appears equally possible to discriminate functional groups, which has interesting implications for mapping PFTs, as well as related ecosystem functions and services (Díaz et al., 2007; Lavorel et al., 2011). It has been noted that the way functional groups are defined influences discrimination success (Harris et al., 2015). Therefore if PFTs that explain more of the variation in the spectra are measured (i.e. optical traits; Ustin and Gamon (2010)), functional groups may be different, and more easily discriminable. Most of the discrimination power was found to be in the ultraviolet A part of the reflectance spectrum, suggesting that spectral differences between functional groups/species are due to mechanisms for sun protection, differences in flavonoid concentrations, or differences in electron transport during photosynthesis (Kolb et al., 2001; Stirbet and Strasser, 1996). Specifically for ecosystem service mapping in wetlands using remote sensing techniques, the PFTs typically measured in the field in 
standard ecological studies should be reviewed.

In this study, the key predictors driving functional groups in South African wetlands were morphological (e.g. leaf area) and biochemical (e.g. cellulose content) and even included root traits (e.g. root type). These PFTs relate to various ecosystem functions, and ultimately influence ecosystem service provision (Table S2). For example at the community scale, morphological traits such as stem diameter, biomass, leaf-length/width ratio, as well as relative amounts of Si, cellulose and lignin in plant tissues would affect flow dynamics within the wetland; vegetation differentially increasing channel roughness by resisting water during high flow events (Moor et al., 2017; Schoelynck et al., 2010). This would ultimately impact the ecosystem services water regulation (flood attenuation) as well as soil retention (erosion control). Another key example is the effect of biochemical traits such as $\mathrm{C} / \mathrm{N}$ concentration, cellulose, lignin and Si content as well as SLA on decomposition within wetlands (Kokaly et al., 2009), which in turn differentially affect ecosystem services such as climate regulation, soil quality and water purification (Moor et al., 2017).

\section{Conclusion}

This research on 22 dominant South African wetland species suggests that it is possible to discriminate functional groups, and even species, based on their reflectance spectra, with reasonable accuracy. This provides an opportunity for further research to build upon these findings to attempt to use such functional groups to map ecosystem processes, or even services, in wetlands.

\section{Acknowledgements}

We gratefully acknowledge the following organizations for funding: The Erasmus Mundus Programme (European Commission), Applied Centre for Climate and Earth System Science (ACCESS) Project Funding, GreenMatter (South Africa), Consolidoc: Stellenbosch University, the Belgian Science Policy Office in the framework of the STEREOIII program (project INPANT (SR/01/321)) and the KU Leuven Research Coordination Office. We thank the reviewers for comments which improved the manuscript.

\section{Appendix A. Supplementary data}

Supplementary data to this article can be found online at https:// doi.org/10.1016/j.rse.2018.02.031.

\section{References}

Adam, E., Mutanga, O., Rugege, D., 2010. Multispectral and hyperspectral remote sensing for identification and mapping of wetland vegetation: a review. Wetl. Ecol. Manag. 18, 281-296. http://dx.doi.org/10.1007/s11273-009-9169-z.

Ali, A.M., Darvishzadeh, R., Skidmore, A.K., Van Duren, I., 2015. Effects of canopy structural variables on retrieval of leaf dry matter content and specific leaf area from remotely sensed data. IEEE J. Sel. Top. Appl. Earth Obs. Remote Sens. 9, 898-909. http://dx.doi.org/10.1109/JSTARS.2015.2450762.

Asner, G.P., 1998. Biophysical and biochemical sources of variability in canopy reflectance. Remote Sens. Environ. 64, 234-253.

Asner, G.P., Martin, R.E., 2008. Spectral and chemical analysis of tropical forests: scaling from leaf to canopy levels. Remote Sens. Environ. 112, 3958-3970. http://dx.doi. org/10.1016/j.rse.2008.07.003.

Asner, G.P., Martin, R.E., 2009. Airborne spectranomics: mapping canopy chemical and taxonomic diversity in tropical forests. Front. Ecol. Environ. 7, 269-276. http://dx. doi.org/10.1890/070152.

Asner, G.P., Martin, R.E., Knapp, D.E., Tupayachi, R., Anderson, C., Carranza, L., Martinez, P., Houcheime, M., Sinca, F., Weiss, P., 2011. Spectroscopy of canopy chemicals in humid tropical forests. Remote Sens. Environ. 115, 3587-3598. http:// dx.doi.org/10.1016/j.rse.2011.08.020.

Baltzer, J.L., Thomas, S.C., 2005. Leaf optical re-sponses to light and soil nutrient availability in temperate deciduous trees. Am. J. Bot. 92, 214-223.

de Bello, F., Lavorel, S., Díaz, S., Harrington, R., Cornelissen, J.H.C., Bardgett, R.D., Berg, M.P., Cipriotti, P., Feld, C.K., Hering, D., Martins da Silva, P., Potts, S.G., Sandin, L., Sousa, J.P., Storkey, J., Wardle, D.A., Harrison, P.A., 2010. Towards an assessment of multiple ecosystem processes and services via functional traits. Biodivers. Conserv.
19, 2873-2893. http://dx.doi.org/10.1007/s10531-010-9850-9.

Carmona, C.P., Rota, C., Azcárate, F.M., Peco, B., 2015. More for less: sampling strategies of plant functional traits across local environmental gradients. Funct. Ecol. 29, 579-588. http://dx.doi.org/10.1111/1365-2435.12366.

Carter, G., Spiering, B., 2002. Optical properties of intact leaves for estimating chlorophyll concentration. J. Environ. Qual. 31 (14244-1432).

Castro, K.L., Sanchez-Azofeifa, G.A., 2008. Changes in spectral properties, chlorophyll content and internal mesophyll structure of senescing Populus balsamifera and Populus tremuloides leaves. Sensors 8, 51-69.

Díaz, S., Lavorel, S., de Bello, F., Quétier, F., Grigulis, K., Robson, T.M., 2007. Incorporating plant functional diversity effects in ecosystem service assessments. Proc. Natl. Acad. Sci. U. S. A. 104, 20684-20689. http://dx.doi.org/10.1073/pnas. 0704716104.

Feilhauer, H., Asner, G.P., Martin, R.E., Schmidtlein, S., 2010. Brightness-normalized partial least squares regression for hyperspectral data. J. Quant. Spectrosc. Radiat. Transf. 111, 1947-1957. http://dx.doi.org/10.1016/j.jqsrt.2010.03.007.

Harris, A., Charnock, R., Lucas, R.M., 2015. Hyperspectral remote sensing of peatland floristic gradients. Remote Sens. Environ. 162, 99-111. http://dx.doi.org/10.1016/j rse.2015.01.029.

Job, N., 2014. Geomorphic Origin and Dynamics of Deep, Peat-filled, Valley Bottom Wetlands Dominated by Palmiet (Prionium serratum) - A Case Study Based on the Goukou Wetland, Western Cape. Rhodes University, Eastern Cape.

Kaufman, Y.J., Remer, L.A., 2002. Detection of forests using mid-IR reflectance: an application for aerosol studies. IEEE Trans. Geosci. Remote Sens. 32, 672-683.

Klančnik, K., Gaberšcik, A., 2016. Leaf spectral signatures differ in plant species colonising habitats along a hydrological gradient. J. Plant Ecol. 9, 442-450.

Klančnik, K., Mlinar, M., Gaberšcik, A., 2012. Heterophylly results in a variety of "spectral signatures" in aquatic plant species. Aquat. Bot. 98, 20-26. http://dx.doi.org/10. 1016/j.aquabot.2011.12.004.

Klančnik, K., Pancic, M., Gaberšcik, A., 2014a. Leaf optical properties in amphibious plant species are affected by multiple leaf traits. Hydrobiologia 737, 121-130. http://dx. doi.org/10.1007/s10750-013-1646-y.

Klančnik, K., Vogel-Mikuš, K., Gaberšcik, A., 2014b. Silicified structures affect leaf optical properties in grasses and sedge. J. Photochem. Photobiol. B Biol. 130, 1-10. http:// dx.doi.org/10.1016/j.jphotobiol.2013.10.011.

Klančnik, K., Gradinjan, D., Gaberšcik, A., 2015a. Epiphyton alters the quantity and quality of radiation captured by leaves in submerged macrophytes. Aquat. Bot. 120, 229-235. http://dx.doi.org/10.1016/j.aquabot.2014.07.007.

Klančnik, K., Zelnik, I., Gnezda, P., Gaberšcik, A., 2015b. Do reflectance spectra of different plant stands in wetland indicate species properties? In: Vymazal, J. (Ed.), The Role of Natural and Constructed Wetlands in Nutrient Cycling and Retention on the Landscape. Springer International Publishing, Switzerland, pp. 1-326. http://dx.doi. org/10.1007/978-3-319-08177-9.

Knapp, A.K., Carter, G.A., 1998. Variability in Leaf Optical properties among 26 species from a broad range of habitats. Am. J. Bot. 85, 940-946.

Kokaly, R.F., Asner, G.P., Ollinger, S.V., Martin, M.E., Wessman, C.A., 2009. Characterizing canopy biochemistry from imaging spectroscopy and its application to ecosystem studies. Remote Sens. Environ. 113, S78-S91. http://dx.doi.org/10.1016/ j.rse.2008.10.018.

Kolb, C.A., Kaser, M.A., Kopecky, J., Zotz, G., 2001. Effects of natural intensities of visible and ultraviolet radiation on epidermal ultraviolet screening and photosynthesis in grape leaves. Plant Physiol. 127, 863-875. http://dx.doi.org/10.1104/pp.010373. research.

Krauss, P., Markstädter, C., Riederer, M., 1997. Attenuation of UV radiation by plant cuticles from woody species. Plant Cell Environ. 20, 1079-1085.

Lavorel, S., Díaz, S., Cornelissen, J.H.C., Garnier, E., Harrison, S.P., Mcintyre, S., Pausas, J.G., Catherine, N.P., Carlos, R., 2007. Plant functional types: are we getting any closer to the Holy Grail? In: Canadell, J.G., DPL, Pataki (Eds.), Terrestrial Ecosystems in a Changing World. The IGBP Series. Springer-Verlag, Berlin Heidelberg, pp. 149-160.

Lavorel, S., Grigulis, K., Lamarque, P., Colace, M.-P., Garden, D., Girel, J., Pellet, G., Douzet, R., 2011. Using plant functional traits to understand the landscape distribution of multiple ecosystem services. J. Ecol. 99, 135-147. http://dx.doi.org/10 1111/j.1365-2745.2010.01753.x.

Legendre, P., Oksanen, J., ter Braak, C.J.F., 2011. Testing the significance of canonical axes in redundancy analysis. Methods Ecol. Evol. 2, 269-277.

Li, Z., Xu, D., Guo, X., 2014. Remote sensing of ecosystem health: opportunities, challenges, and future perspectives. Sensors 14, 21117-21139. http://dx.doi.org/10. $3390 /$ s141121117.

Lukeš, P., Stenberg, P.T., Mõttus, M., 2013. Optical properties of leaves and needles for boreal tree species in Europe. Remote Sens. Lett. 4, 667-676. http://dx.doi.org/10. 1080/2150704X.2013.782112.

de Marín, S.T., Novák, M., Klančnik, K., Gaberščik, A., 2016. Spectral signatures of conifer needles mainly depend on their physical traits. Pol. J. Ecol. 64, 1-13. http://dx.doi. org/10.3161/15052249PJE2016.64.1.001.

Mevik, B., Wehrens, R., 2007. The pls package: principal component and partial least squares regression in R. J. Stat. Softw. 18, 1-23.

Midgley, D.C., Pitman, W.V., Middleton, B.J., 1994. Surface Water Resources of South Africa 1990 Volume III: Orange-Namaqualand. Pretoria.

Moor, H., Rydin, H., Hylander, K., Nilsson, M.B., Lindborg, R., Norberg, J., 2017. Towards a trait-based ecology of wetland vegetation. Int. J. Lab. Hematol. http://dx.doi.org/ 10.1111/ijlh.12426.

Mueller-Dombois, D., Ellenberg, H., 1974. Aims and Methods of Vegetation Ecology. Wiley, pp. 93-135. http://dx.doi.org/10.1016/0304-3746(75)90017-7.

Nel, J., Driver, A., Strydom, W., Maherry, A., Petersen, C., Hill, L., Roux, D., Nienaber, S., van Deventer, H., Swartz, E., Smith-Adao, L., 2011. Atlas of freshwater ecosystem 
priority areas in South Africa: maps to support sustainable development of water resources. In: WRC Report No. TT 500/11.

Nsor, A.C., 2007. Plant Community Distribution and Diversity, and Threats to Vegetation of the Kromme River Peat Basins, Eastern Cape Province, South Africa (MSc Thesis). Rhodes University.

Ouyang, Z.T., Gao, Y., Xie, X., Guo, H.Q., Zhang, T.T., Zhao, B., 2013. Spectral discrimination of the invasive plant Spartina alterniflora at multiple phenological stages in a saltmarsh wetland. PLoS One 8, 1-12. http://dx.doi.org/10.1371/journal.pone. 0067315.

Pérez-Harguindeguy, N., Díaz, S., Garnier, E., Lavorel, S., Poorter, H., Jaureguiberry, P., Cornwell, W.K., Craine, J.M., Gurvich, D.E., Urcelay, C., Veneklaas, E.J., Reich, P.B., Poorter, L., Wright, I.J., Ray, P., Enrico, L., Pausas, J.G., De Vos, A.C., Buchmann, N., Funes, G., Hodgson, J.G., Thompson, K., Morgan, H.D., Steege, H., Van Der Heijden, M.G.A., Sack, L., Blonder, B., Poschlod, P., Vaieretti, M.V., Conti, G., Staver, A.C., Aquino, S., Cornelissen, J.H.C., 2013. New handbook for standardised measurement of plant functional traits worldwide. Aust. J. Bot. 61, 167-234.

Poona, N.K., Ismail, R., 2013. Discriminating the occurrence of pitch canker fungus in Pinus radiata trees using QuickBird imagery and artificial neural networks. South. For. J. For. Sci. 75, 29-40.

Rebelo, A.G., Boucher, C., Helme, N., Mucina, L., Rutherford, M.C., M.C., 2006. Fynbos biome. In: Rutherford, L.M. (Ed.), The Vegetation of South Africa, Lesotho and Swaziland. SANBI, Pretoria, pp. 50-80.

Rebelo, A.J., Le Maitre, D.C., Esler, K.J., Cowling, R.M. 2015. Hydrological responses of a valley-bottom wetland to land-use/land-cover change in a South African catchment: making a case for wetland restoration. Restor. Ecol. 23, 829-841. http://dx.doi.org/ 10.1111/rec.12251.

Roelofsen, H.D., Van Bodegom, P.M., Kooistra, L., Witte, J.M., 2014. Predicting leaf traits of herbaceous species from their spectral characteristics. Ecol. Evol. 4, 706-719. http://dx.doi.org/10.1002/ece3.932.

Ross, I., 1981. The Radiation Regime and Architecture of Plant Stands. pp. 391. http://dx. doi.org/10.1007/978-94-009-8647-3.

Roth, K.L., Roberts, D.A., Dennison, P.E., Alonzo, M., Peterson, S.H., Beland, M., 2015. Differentiating plant species within and across diverse ecosystems with imaging spectroscopy. Remote Sens. Environ. 167, 135-151. http://dx.doi.org/10.1016/j.rse. 2015.05.007.

Roth, K.L., Casas, A., Huesca, M., Ustin, S.L., Alsina, M.M., Mathews, S.A., Whiting, M.L., 2016. Leaf spectral clusters as potential optical leaf functional types within California ecosystems. Remote Sens. Environ. 184, 229-246. http://dx.doi.org/10.1016/j.rse. 2016.07.014.

Schoelynck, J., Bal, K., Backx, H., Okruszko, T., Meire, P., Struyf, E., 2010. Silica uptake in aquatic and wetland macrophytes: a strategic choice between silica, lignin and cellulose? New Phytol. 186, 385-391. http://dx.doi.org/10.1111/j.1469-8137.2009. 03176.x.

Serbin, S.P., Singh, A., McNeil, B.E., Kingdon, C.C., Townsend, P.A., 2014. Spectroscopic determination of leaf morphological and biochemical traits for northern temperate and boreal tree species. Ecol. Appl. 24, 1651-1669.

Sieben, E.J.J., 2012. Plant functional composition and ecosystem properties: the case of peatlands in South Africa. Plant Ecol. 213, 809-820. http://dx.doi.org/10.1007/ s11258-012-0043-3.

Silva, T.S., Costa, M.P., Melack, J.J., Novo, E.M.L.M., 2008. Remote sensing of aquatic vegetation: theory and applications. Environ. Monit. Assess. 140, 131-145.

Sims, D.A., Gamon, J.A., 2003. Estimation of vegetation water content and photosynthetic tissue area from spectral reflectance: a comparison of indices based on liquid water and chlorophyll absorption features. Remote Sens. Environ. 84, 526-537. http://dx.doi.org/10.1016/S0034-4257(02)00151-7.

SPSS, 2001. The SPSS TwoStep Cluster Component. A Scalable Component to Segment Your Customers More Effectively. (White paper - technical report).

Stirbet, A.D., Strasser, R.J., 1996. Numerical simulation of the in vivo fluorescence in plants. Math. Comput. Simul. 42, 245-253. http://dx.doi.org/10.1016/03784754(95)00114-X.

Tilman, D., 2001. Functional Diversity, Encycloped. Academic Press, New York.

Tuominen, J., Lipping, T., 2016. Spectral characteristics of common reed beds: studies on spatial and temporal variability. Remote Sens. 8. http://dx.doi.org/10.3390/ rs8030181.

Ustin, S.L., Gamon, J.A., 2010. Remote sensing of plant functional types. New Phytol. 186, 795-816.

Ustin, S.L., Gitelson, A.A., Jacquemoud, S., Schaepman, M., Asner, G.P., Gamon, J.A., Zarco-tejada, P., 2009. Retrieval of foliar information about plant pigment systems from high resolution spectroscopy. Remote Sens. Environ. 113, S67-S77. http://dx. doi.org/10.1016/j.rse.2008.10.019.

Van Cleemput, E., Vanierschot, L., Fernandez-Castilla, B., Honnay, O., Somers, B., 2018. The functional characterization of grass- and shrubland ecosystems using hyperspectral remote sensing: trends, accuracy and moderating variables. Remote Sens. Environ. http://dx.doi.org/10.1016/j.rse.2018.02.030.

Van Soest, P.J., 1963. Use of detergents in the analysis of fibrous feeds. II. A rapid method for the determination of fiber and lignin. J. Assoc. Off. Agric. Chem. 46, 829-835.

Zhang, Y., Chen, J.M., Miller, J.R., Noland, T.L., 2008. Leaf chlorophyll content retrieval from airborne hyperspectral remote sensing imagery. Remote Sens. Environ. 112, 3234-3247. http://dx.doi.org/10.1016/j.rse.2008.04.005. 